\title{
Durability of the Authoritarian Regimes: The Role of Procedural Factors
}

\author{
Stanislav Nikolaevich Shkel ${ }^{1} \&$ Eduard Sagidulovich Gareev $^{1}$ \\ ${ }^{1}$ Ufa State Petroleum Technological University, Russian Federation \\ Correspondence: Stanislav Nikolaevich Shkel, Kosmonavtov Str., 1, Ufa, Republic of Bashkortostan, 450062, \\ Russian Federation. E-mail: info@rusoil.net
}

\author{
Received: February 3, 2015 Accepted: May 10, 2015 Online Published: July 30, 2015 \\ doi:10.5539/ass.v11n19p205 URL: http://dx.doi.org/10.5539/ass.v11n19p205
}

\begin{abstract}
The article proposes the theoretical framework for analysis of procedural factors of stability of authoritarian regimes. Following the conceptual provisions of the J. Gerschewski about three key strategies autocrat (legitimation, repression and co-optation), highlighted in the main functions that perform these strategies in relation to the three main subjects of the interaction of an authoritarian leader. It is pointed out that the interaction of an authoritarian leader linked to the three main political actors: the electorate, insiders and outsiders. The key procedural factor of stability of the authoritarian regime is the ability of a political leader to form a coalition loyal to conquer, including the main segments of the influential elite (insiders). Sustainability also the weakness of the elite segment depends on authoritarianism loyalty of major social groups (the electorate), the marginalization of the opposition and who are not included in the ruling coalition (outsiders). Achieving these objectives relate to the possibility of the leader to hold three major strategies: cooptation, repression and legitimation, respecting the proportionality and timeliness of their application. The article concludes that sustainability of authoritarian regimes depends on the capabilities of authoritarian leader to use the above strategies for consolidation and stabilization of their power. At the same time, the efficiency of authoritarianism is not only connected with power resources and capabilities repressive suppression of opponents, but no less with the ability to use the whole range of strategies in adequate proportions. Abuse in the use of only one of the three possible strategies leads to the risk of destabilizing the regime.
\end{abstract}

Keywords: political regimes, political institutions, non-democratic regimes, authoritarianism, political leadership

\section{Introduction}

The researchers' optimism about relatively democratic trends in regime transformations in the states of Africa, Eastern Europe and the former USSR has resulted in a dramatic drop of interest towards authoritarianism during the 1990s. However, on the eve of the XXI century the political realia, as well as the increased awareness of the approaching third wave of democratization (Diamond, 1996), have initiated a next step in increasing the researchers' interest to non-democratic regimes. Indeed, as per the data of Freedom House analytical center, the difference between democratic regimes and autocracies has remained the same within the period of 2001 to 2012, existing variations being irrelevant. Thus, in 2001 of 192 states of the world the "free" countries amounted to 47.7\% ( $\mathrm{N}=86)$, the "partially free" countries comprised $30.2 \%(\mathrm{~N}=58)$, whereas the "non-free" made up 25\% $(\mathrm{N}=48)$ (Freedom in the World, 2001). The situation has not changed considerably 10 years after. In 2012, in their report on the political the experts of the organization considered $46.1 \%(\mathrm{~N}=90)$ of 195 countries under research to be "free", $29.7 \%(\mathrm{~N}=58)$ were declared "partially free" and $24.1 \%(\mathrm{~N}=48)$ of the countries "non-free" (Freedom in the World, 2013). Even though it will be premature to speak of the third authoritarian rollback, the thesis of L. Diamond on equilibrium and stabilization phase in global political dynamics (which he proposed back in late 1990s) (Diamond, 1996) looks quite realistic nowadays.

In this connection, an issue of sustainability factors of non-democratic regimes is becoming extremely topical at the present stage. In this article, a theoretical model is provided, within the framework of which the principal procedural factors for authoritarian sustainability have been systematized. 


\section{Method}

Following the fundamentals of Selectorate Theory, it can be assumed that sustainability of a non-democratic regime depends on the autocrat's ability to form a loyal empowered coalition that includes the principal segments of influential elites (Mesquita, 2003). The said elite groups will be defined as "insiders" within the framework of the present research model. The authoritarian sustainability also depends on loyalty of principal social groups (electorate), as well as on the degree of opposition marginalization and on the weakness of the elite segments not included into an empowered coalition. The opposition and the elite not incorporated into the system of power will be collectively defined as "outsiders". Thus, an authoritarian ruler in the most general sense interacts with the following three political actors:

1. Electorate, which includes the most various social classes.

2. Insiders, i.e. the members of the elites incorporated into the empowered coalition.

3. Outsiders, i.e. the opposition and the elite segments outside of the empowered coalition.

What specific mechanisms and strategies do authoritarian rulers use to keep the social groups and the insiders loyal and the outsiders - away from the political influence?

J. Gerschewski (2013) singles out the following three authoritarian strategies: legitimation, repression and co-optation. Following these conceptual provisions there can be established the principal functions which these strategies perform in regards to the three main subjects of the authoritarian leader's interaction. In general, Table 1 displays all the principal functions of the three main strategies ensuring the stable functioning of an authoritarian regime.

Table 1. The functions of the three strategies of authoritarian government in regards to principal political actors

\begin{tabular}{llll}
\hline Strategies & Insiders & Outsiders & Actors \\
\hline \multirow{2}{*}{ Co-optation } & $\begin{array}{l}\text { Forming loyalty and } \\
\text { maintaining elite } \\
\text { fragmentation }\end{array}$ & $\begin{array}{l}\text { Splitting and marginalizing } \\
\text { opposition }\end{array}$ & $\begin{array}{l}\text { Ensuring feedback through } \\
\text { monitoring requirements, } \\
\text { ideas and cadres }\end{array}$ \\
Repression & $\begin{array}{l}\text { Increasing the disloyalty price } \\
\text { and maintaining elite } \\
\text { fragmentation }\end{array}$ & $\begin{array}{l}\text { Increasing the disloyalty price } \\
\text { and maintaining elite } \\
\text { fragmentation }\end{array}$ & $\begin{array}{l}\text { Increasing the political } \\
\text { mobilization price }\end{array}$ \\
Legitimation & $\begin{array}{l}\text { Maintaining loyalty on the } \\
\text { basis of lack-of-options idea }\end{array}$ & $\begin{array}{l}\text { Maintaining loyalty on the } \\
\text { basis of lack-of-options idea }\end{array}$ & $\begin{array}{l}\text { Forming a social support base } \\
\text { on the basis of propaganda }\end{array}$ \\
\hline
\end{tabular}

\section{Results and Discussion}

Co-optation can be defined as strategic measures of an authoritarian ruler directed at forming sustainable connections of the regime with the elites and social groups with the aim of preserving their loyalty. This strategy is a key one in terms of forming an empowered coalition.

\subsection{Co-optation Functions for Insiders}

The sustainability of commanding positions of a ruler is directly proportional to co-optation abilities of a regime, as well as to the empowered coalition size. Of fundamental importance is co-optation of regional elites, national security bureaucracy and business representatives. The sustainable functioning of a regime becomes unlikely without the loyalty of the given insider group.

At the same time, the regime sustainability depends not only on the size of an empowered coalition, but also on its elite structure format. Though co-opting insiders into an empowered coalition creates the basis for elite integration, an excessive monolithic stature of elite networks poses a threat to a dictator. Excessively consolidated elite can easily solve a "collective action" problem and unite against a ruler. The monolithic stature of insiders becomes a power limiter for a dictator and hence considerably increases the risks of intra-elite conspiracy. A bipolar elite structure of an empowered coalition is also potentially unstable and prone to conflicts. The insider elite groups split into two factions preserve their status quo only on condition that the resources are equally distributed between those factions. However, any imbalance or change in estimated resource distribution provokes controversies between the elite groups, which results in regime instability (Gel'man, 2008). The most sustainability to an authoritarian regime is provided by an empowered coalition which includes fragmented elite. 
Although, within the framework of democratization theory, elite fragmentation is often viewed as a source for competition and making formal game rules contributing to democracy institutionalization (Weingast, 1997). In case of co-opted elites functioning within a patronal network, fragmented elite structure makes it considerably simpler for an authoritarian leader to use a "divide-and-rule" strategy, as well as to maintain insiders' loyalty (Acemoglu, Robinson, \& Verdier, 2004). Therefore, the logic of authoritarian sustainability requires a ruler to co-opt new elite segments into an empowered coalition, thus "diluting" factions to ensure the equality of their resources, maintaining a moderate level of competition between them and preserving a situation in which coordinating and solving a "collective action" problem would be most difficult. When every separate faction is relatively weak, the leader's potential to change the insiders' commanding positions within the patronal network hierarchy increases (Shkel, 2014). An intra-elite competition increases the levels of distrust between elite segments and at the same time, it creates stimuli for loyalty to a ruler, who begins to act as a main guarantor of maintaining the insiders' positions. Consequently, fragmenting elites in an authoritarian environment increases the support of a ruler by insiders who become interested in maintaining the regime equilibrium unchanged, since a perspective change of a ruler creates uncertainty and sets off a new open confrontation between elite factions, the outcome of which is extremely difficult to assess in terms of benefits and downsides for every group of competing elites.

Thus, the co-optation strategy can perform the following two principal functions in regards to insiders: forming loyalty of the empowered coalition members and keeping its structure fractionated.

\subsection{Co-optation Functions for Outsiders}

In regards to outsiders, co-optation performs the functions of splitting and marginalizing the opposition. It is for this very purpose that many authoritarian regimes use such formal channels as parties, legislatures and elections (Gandhi \& Przeworski, 2007). Using these institutions, a regime co-opts a part of oppositional actors into an empowered coalition, which leads to splitting and weakening of the opposition. In case of electoral authoritarianism (Schedler, 2006), a key incumbent problem is the opposition's ability to integrate and present a united political bloc (Bunce \& Wolchik, 2010). Partially co-opting the opposition members through providing them with seats in representative authority bodies leads to splitting the opposition and forming its dualistic structure which consists, according to J. Linz, of principled (non-system) opposition and of loyal (system) semi-opposition (Linz, 1978). Using the co-optation strategy, a regime strives for marginalizing the opposition in a sense that, having lost the stimuli to coordinate, the opposition loses the ability to provide electoral competition to an incumbent. Members of the loyal semi-opposition receive only a minimum of commanding positions, which prevents them from influencing the political policy. The principled opposition is altogether ousted out of the framework of institutional political space, the only strategy of political struggle left possible for the said opposition being protest actions. However, the "non-system" opposition has limited abilities of mass mobilization due to being split and fragmented, so their attempts to threaten the regime with direct actions are stopped through pinpoint repressions.

Moreover, integrating a part of independent actors into an empowered coalition as "system opposition" creates a logic of a political game within the framework of which with oppositional actors there arise the stimuli to compete with each other, but not with an incumbent. Members of loyal semi-opposition holding seats in legislative assemblies through cartel agreement concluded with the authorities become uninterested in expanding competition and democratization since those are a threat to the position of such members. Should the role of electorate in obtaining commanding positions increase, a significant share of seats (if not all seats) in a legislative assembly held by the members of "system" opposition can pass to the representatives of "non-system" opposition. As the result, the members of loyal semi-opposition unanimously support the regime and their position considerably reduces the expansion of political freedom and competition.

\subsection{Co-optation Functions for Electorate}

One of the main problems of non-democratic regimes is their poor feedback to the society. In the absence of competitive elections and elite rotation, a regime becomes insensitive to changes in public mood and experiences difficulties with an unbiased appraisal of goalposts of different social groups. Co-opting wider sections of the public into various formal structures can partially solve the above problems. With this aim in view, a regime establishes various organizations, - starting from controllable political parties and civic movements to Public Chambers and Assemblies of Nations, called for to integrate wider social strata for the purpose of establishing contacts with the state authorities and exchanging information between them. The authorities also form various mechanisms of selection and recruitment (Youth Parliaments, youth movements, candidate pools) to select cadres, thus accomplishing a task of elite replacement (Shkel, 2009). All the above bodies are of corporate and 
not democratic character since they are not independent from the authorities and provide no competitions to ruling subjects. In such a way, a regime ensures monitoring new ideas, perspective cadres with no threat to its monopoly and establishes feedback channels to the society.

\subsection{Repression}

In political science, repressions are most often understood as "actions or threats to apply physical sanctions against certain persons or organizations within the framework of territorial jurisdiction with the aim of increasing the price of political activities, as well as to suppress oppositional actions or convictions" (Goldstein, 1978; Davenport, 2007). However, in this paper we will assume a wider understanding of repressions as interpreted by R. Wintrobe, who includes in this notion not only violent actions or physical intimidation, but any actions of the authorities limiting political freedom of citizens (Wintrobe, 1998). In this sense, legislative initiatives to reduce media freedom or refusal to register oppositional candidates and parties are considered to be repressive practices.

\subsection{Repression Functions for Insiders}

Following from a classic definition of repressions, the main function of this strategy applied by the authorities is to increase the price of political activities. For insiders it means increasing price for their choices of disloyal activity against an autocrat. Since intra-elite coup is often the most critical threat for a dictator, repressions are intended to increase downsides for coup initiators or potential participants to the maximum.

Furthermore, an authoritarian ruler needs repressions to maintain elite fragmentation. As it has already been discussed above, a fragmented elite structure is one of the conditions of authoritarian sustainability. Using repressions, a dictator weakens strengthened contenders and performs rotations and staff transfers to prevent elites from being monolithic, as well as to expand the area to conduct "divide-and-rule" policy.

\subsection{Repression Functions for Outsiders}

With regards to outsiders, repressions perform a function of increasing the price of anti-government activities and serve as a mechanism of maintaining oppositional split. Having established a dual structure of oppositional actors and having included the "system" opposition into an empowered coalition, with the help of repressions a regime prevents the "system" opposition from the attempts to get out of control and unite with the bloc of "non-system" opposition, the possibility of which arises during recession or other situation of general instability of society development.

\subsection{Repression Functions for Electorate}

Repressions towards electorate are aimed at increasing the price of supporting the opposition. Equally important function of repressions is preventing social groups from participating in protest actions. Alongside with the risks of intra-elite conspiracy, political mobilization and protest activity from below presents the most dangerous threats for non-democratic regimes. It is precisely for keeping the society away from mass mobilization that a regime uses methods of deterrents and repressions in regards to a wider scope of persons than solely oppositional politics and activists.

\subsection{Legitimation}

Although the mechanisms of regime legitimation within the framework of totalitarianism paradigm have been the center of the researchers' attention, this aspect is at the periphery of the researchers' interest in most of the late authoritarianism theories. Quite widespread has become a certain point of view stating that legitimation is of no significance for an authoritarian leader since his power does not rest on the opinion of the most people. At the same time, the current political regalia connected with globalization and informatization allows for considering ideological and legitimation aspects of authoritarian sustainability are becoming equally important. The strategies of co-optation and repressions require considerable economic resources, which makes functioning of the regime based solely on the said mechanisms excessively expensive.

J. Gerschewski (2013) considers legitimation to be the most important support of the modern authoritarianism forms, integrating this strategy (alongside with co-optation and repressions) into an analytical framework developed by him to research authoritarian sustainability. Following his methodological provisions, legitimation can be defined as the incumbent's mechanisms directed at structuring connections between the authorities and the society with the aim of forming active support, complying with the established regulations, passive obedience or mere tolerance towards the authorities on the part of elites and wide social strata.

The mechanisms of legitimation practices themselves can be quite various, including indoctrination of ideological right or left-inclined systems, usage of nationalistic or religious ideologemes, cultivation of populism and charisma of a leader, positioning of economic success of a regime, stereotype formation with the help of 
propaganda, promoting fear and enemy stereotypes with the population to persuade them of the necessity to toughen a regime for the sake of safety of the society, etc. Overall, the diversity of the above measures is united by the main goal of a regime which is convincing the principal social subjects of expediency of preserving the current power structure, as well as convincing them of fairness of the appropriate rulers being at the top of the said structure. At the same time, functions of legitimation have their own specifics in regards to different political actors.

\subsection{Legitimation Functions for Insiders}

Legitimation in regards to insiders is of purely pragmatic nature. It forms the conviction among the elite that preserving an autocrat in power is expedient as the best possible guarantee of sustainability of their positions and benefits. In this case, legitimation is not so much ideology or a set of values as an informal elite agreement on division of spheres of influence and on annuity distribution obligations. The dictator's sustainability is maintained until principal elite segments of an empowered coalition are convinced that the existing ruler serves their interests, ensures their position safety and minimizes risks of encroachment on their positions both from the side of competing elite factions and from the outsiders.

\subsection{Legitimation Functions for Outsiders}

According to Bunce and Wolchik, one of the problems of oppositional actors in an authoritarian environment is the absence of belief in their chances to defeat an incumbent (Bunce \& Wolchik, 2010). Spread of pessimism among the opposition leads to passivity and errors in strategic planning of political struggle. Legitimation functions for outsiders are in forming the above pessimism and developing a conviction based on the idea of invincibility of an authoritarian leader. To achieve this, both means of propaganda and electoral practices are used. Issuing from the experience of political development in Mexico, B. Magaloni convincingly discloses the reasons for autocrats to necessarily strife for not just electoral superiority over the opposition, but for superiority with a considerable preponderance. According to her, in so doing a regime legitimizes its domination by demonstrating that the power of incumbents rests on mass support. At that, this support is so obvious that the opposition has no chances to succeed. Maintaining the opposition's pessimism as the result of such electoral practices keeps insiders integrated and prevents potentially oppositional business from supporting outsiders (Magaloni, 2006). The authorities are interested in preserving the projected image of the opposition as that of pathetic losers having no social basis and political perspectives. In its turn, it influences the oppositional environment in which pessimism is preserved resulting in less offensive strategy and underestimation of its own potential.

\subsection{Legitimation Functions for Electorate}

As it has already been discussed above, sustainability of the present-day authoritarian regimes is seldom based solely on "fear and bribery". At least, both autocracies and democracies need mass support for long-term stability. The specifics of non-democratic regimes are that their social basis is not formed through competitive elections, but through propaganda and political technologies. Incumbents can use a wide selection of ideologemes the main purpose of which is to convince electorate of usefulness and fairness of the existing authorities.

Besides, authoritarian regimes often effectively use democratic elements for legitimation purposes. In particular, election institutions or referendums serve for autocrats as the means of demonstrating their mass support. Although the above-mentioned is performed without any compliance with the basic principles of equality and fair competition and the political rivalry elements are strictly within the framework of "virtual politics" (Wilson, 2005), convincing electoral results are of considerable significance to maintain loyalty of a large share of apolitical citizens who form the basis of a "median voter". It is this very part of electorate that cements an authoritarian majority with the help of which a regime gains sustainability and minimizes the risks of mass political mobilization.

\section{Conclusion}

Finishing the discussion of the principal functions of the three main strategies which determine authoritarian sustainability, it should be noted that authoritarian sustainability depends on leader's ability and possibility to use all the range of the discussed means. In other words, "an ideal dictatorship" is based not on separate mechanisms, but on the whole range of mechanisms, as well as on autocrat's ability to effectively variate those depending on the political process dynamics. The problem for an authoritarian rule is that every discussed strategy has certain downsides and threats. Therefore, it is only the joint use of co-optation, repressions and legitimation that can minimize the risks involved in using each of the mechanisms. 


\section{References}

Acemoglu, D., Robinson, J., \& Verdier, T. (2004). Kleptocracy and Divide and Rule. Journal of the European Economic Association, 2(2-3), 162-192. http://dx.doi.org/10.1162/154247604323067916

Bunce, V. J., \& Wolchik, S. L. (2010). Defeating Dictators: Electoral Change and Stability in Competitive Authoritarian Regimes. World Politics, 62(1), 43-86. http://dx.doi.org/10.1017/S0043887109990207

Davenport, C. (2007). State Repression and Political Order. Annual Review of Political Science, 10, 1-23. http://dx.doi.org/10.1146/annurev.polisci.10.101405.143216

De Mesquita, B. B., Smith, A., Siverson, R., \& Morrow, J. M. (2003). The Logic of Political Survival. Cambridge, MA: The MIT Press.

Freedom in the World 2001. Retrieved from http://www.freedomhouse.org/report/freedom-world/freedom -world-2001

Freedom in the World 2013. Retrieved from http://www.freedomhouse.org/report/freedom-world/freedom -world-2013

Gandhi, J., \& Przeworski, A. (2007). Authoritarian institutions and survival of autocrats. Comparative political studies, 40(11), 1279-1301. http://dx.doi.org/10.1177/0010414007305817

Gel'man, V. (2008). Out of the Frying Pan, into the Fire? Post-Soviet Regime Changes in Comparative Perspective. International Political Science Review, 29(2), 157-180. http://dx.doi.org/10.1177/0192512 107085610

Gerschewski, J. (2013). The three pillars of stability: Legitimation, repression, and co-optation in autocratic regimes. Democratization, 20(1), 13-38. http://dx.doi.org/10.1080/13510347.2013.738860

Goldstein, R. (1978). Political Repression in Modern America: from 1870 to the Present. Cambridge, MA: Schenkman.

Linz, J. (1978). Opposition to and under an Authoritarian Regime: The Case of Spain. Regimes and Oppositions. New Haven and London: Yale University Press.

Magaloni, B. (2006). Voting for Autocracy: Hegemonic Party Survival and Its Demise in Mexico. Cambridge, UK: Cambridge University Press. http://dx.doi.org/10.1017/CBO9780511510274

Schedler, A. (2006). The logic of electoral authoritarianism. Electoral Authoritarianism: The Dynamics of Unfree Competition. Boulder, London, UK: Lynne Rienner Publishers.

Shkel, S. (2009). The Political Regime in Kazakhstan: its Current State and Possible Future. Central Asia and The Caucasus, 6(60), 101-108.

Shkel, S. (2014). Political Regimes of the Post-Soviet States of the Central Asia and Caucasus. Sententia. European Journal of Humanities and Social Sciences, 4, 322-330.

Weingast, B. (1997). The Political Foundations of Democracy and the Rule of Law. American Political Science Review, 91(2), 245-263. http://dx.doi.org/10.2307/2952354

Wilson, A. (2005). Virtual Politics: Faking Democracy in the Post-Soviet World. New Haven \& London: Yale University Press.

Wintrobe, R. (1998). The political economy of dictatorship. NY: Cambridge University Press. http://dx.doi.org /10.1017/CBO9781139174916

\section{Copyrights}

Copyright for this article is retained by the author(s), with first publication rights granted to the journal.

This is an open-access article distributed under the terms and conditions of the Creative Commons Attribution license (http://creativecommons.org/licenses/by/3.0/). 